\title{
Islam and the Cyber World
}

\author{
Abdi O. Shuriye \\ Mosud T. Ajala \\ Engineering, Kulliyyah of Engineering, International Islamic University, Malaysia, \\ P.O. Box 10, 50728 Kuala Lumpur, Malaysia \\ shuriye@hotmail.com, mosud.ajala@yahoo.com
}

\section{Doi:10.5901/jesr.2014.v4n6p513}

\section{Abstract}

The mixed reactions on the use of the internet technology which have resulted in different debates and crimes in the cyber world calls for assessment of the Islamic point of view of the issue. Cyber world created avenue for the Muslim Ummah in a form of virtual global community and it encouraged dialogue as well as access to information on a real time basis; and above all facilitated easy access to the Qur'an. Nonetheless, th same tool has opened doors for crimes such as pornography, victimization, bullying, stalking etc. Hence this study reviews the benefits of the internet technology and consequences of its misuse. The frame of reference in measuring both the negative and positive aspects of this technology will be the Islamic standpoint.

\section{Introduction}

Obviously, to begin with, Islam, as a universal code of mercy, is an impeccable and all-inclusive Deen. Allah reminds: "... This day I have perfected for you your religion and completed My favour upon you and have approved for you Islam as religion..."(Al-Qur'an, al-Maidah:3); "Indeed this Qur'an guides to the path which is clearer and straighter than any other" (Al-Qur'an, al-Israi:9). Islam through Al-Qur'an has touched all aspect of human endeavour, Allah the almighty said: "We have revealed to you the book which clarifies every matter" (Al-Qur'an, al-Nahl:89) and "And there is no creature on [or within] the earth or bird that flies with its wings except [that they are] communities like you. We have not neglected in the Register a thing. Then unto their Lord they will be gathered. (Al-Qur'an, Al-An'am:38). Al-Suyuti using these two verses of Surah al-Nahl and al-An'am argues that Al-Qur'an contains all sciences. Imam Al-Ghazali, also affirm that Al-Qur'an is a source of both ancient and modern knowledge. The Qur'an contains series of beneficial knowledge to humanity such happenings in the past, information about the future, lawful and unlawful things and knowledge about worldly affairs, religion, livelihood, and the Hereafter. Therefore, Islam encourages development, knowledge and education, Allah says: "Recite in the name of your Lord who created; Created man from a clinging, substance; Recite, and your Lord is the most Generous; Who taught by the pen; Taught man that which he knew not" (Al-Qur'an, al-'Alaq:15). It also contains general principles applicable to all times and places as well as the importance of seeking both divine and worldly knowledge.

There are two major types of knowledge in Islam. The first type is the divine knowledge while the other type is that acquired through man's effort of rational probe based on experience and surveillance (Al-Naquib-Al-Attas, 1978). Yousif's study (as cited in Muhammad and Muhammad, 2003) explains that "the latter form of knowledge includes tanzur (observation), tadabbur (deliberation), tathakkur (recollection), tafakkur (consideration), tabassur (understanding) and ta'aqul (rationalization). All these mechanism have been mentioned in Al-Qur'an". Therefore cyber technology which is a baby of the Information, Communication and Technology (ICT) lies in this second category.Klastrup \& Tosca (n.d.) defines cyber worlds as:

\footnotetext{
"Computer-mediated, networked and spatially navigable multi-user environments that contain the possibility to interact in real time with other users and to actively interact with and influence the world itself. They can be game worlds or entertainments world or social worlds, but most cyberworlds provide all three opportunities (gaming, being entertained, socialising) in some form" (Klastrup \& Tosca, n.d.).
}

Kunii $(2003,2004)$ describes cyber worlds as "worlds created on cyberspaces as computational spaces either intentionally or spontaneously, with or without design". The world has been described with different words such as virtual 
world, digital world synthetic world and Cyber environment (Mohamed, 2011).

Mohamed (2011) affirm that "internet has become most popular medium of communication in cyber environment" , therefore discussion on Islam and the cyber world will also focus on the benefits of the most popular means of communication through which the cyber world is created. The study of Zaidi (2012) on parenting and the cyber world that focused on the impact of the internet technology is an example. Dow and Condit (as cited in El-Nawawy \& Khamis, 2009) asserts that "the most influential technological development is the internet". Wellman and Gulia (as cited in El-Nawawy \& Khamis, 2009) stated that "operating via the Net, virtual communities are globalized...".

The internet - a place with no security- assists development in nearly all facet of our society. It is obtainable and easy to get in virtually every corner of the world. It has offered innumerable benefits to humanity. From the development of the worldwide buying and selling to progresses in education and health upkeep, this tool has brought about changes in mode of communication. Its unrestricted access to all - convicts, ex-convicts, parents, teenagers, responsible, annoyed, dejected and sick-minded people etc - brings about the concern and need to manage the cyber world. Michael L. Pitaro (n.d.) argues:

\begin{abstract}
"...the Internet, with its infinite size and previously unimaginable capabilities, has a dark side, too. It has opened windows of previously unknown criminal opportunities that not only challenge but also transcend all physical boundaries, borders, and limitations that work to detect, punish, and diminish what appears to be a growing social problem of global proportions..." (Michael L. Pitaro, n.d.)
\end{abstract}

These pointed out the fact that the internet is a double edged sword.

Rheingold (as cited in El-Nawawy \& Khamis, 2009, 59) concludes that "the technology will not itself fulfil [the democratization] potential; the internet must be used intelligently and deliberately by an informed population". According to Wheeler as (as cited in El-Nawawy \& Khamis, 2009, 59), "the meaning and implication of the [technological] tool are found in society's use of technology, and this is why we see the same tool, the internet, having different meanings in a variety of contexts." This implies that the end product of the internet technology as seen and felt in the cyber world is a function of the consumer's social practise. The internet has been adjudged - religiously, socially and ethically- to have both positive and negative implication. El-Nawawy \& Khamis (2009) quoting the opinion of Omar Eldeeb, a scholar in AlAzhar on Muslims and the internet states: "Islam is being attacked through the internet, Muslims should use the same weapon to defend themselves by developing the skills that would allow them to use the internet". In the comment of Alsersawy, El-Nawawy \& Khamis (2009) reported that: "he sees the internet as a complimentary tool to the preacher's role though has it downside, Muslims should not isolate and reject the new technologies because doing that will bring serious repercussions on the Islamic community". Yusuf Qaradawi an erudite scholar also approves its usess. In an interview with Al-Jazeerah TV he points out that:

\begin{abstract}
"...certain Muslims in the past had negative views of technology. They considered some of them, like the telephone and other devices, to be the work of Satan. He cites verses from the Koran to prove that inventions are discussed in Islam: "And (He has created) horses, mules and donkeys, for you to ride and use for show; and He has created (other) things of which ye have no knowledge." Al-Qaradawi says that in this Koranic verse, the phrase "of which ye have no knowledge" includes "cars, trains, aircraft and spaceships". He says this is the age of "revolutions in science." AlQaradawi says that all devices are means that can be used for either vice or virtue. He says: "Take the rifle, for instance. In the hand of a bandit, the rifle is a vice because it will help him do evil and commit murders. However, in the hand of the mujahid, it is a tool for virtue, jihad and self-defence and for defending religion and the nation." This also applies to the internet and "what use we make of it". He says: "If we want to use it for corruption, sexual material and pornography and to spread hate," then it would be unlawful. He says: "We can use this wonderful device in teaching Muslims about Islam and in calling non-Muslims to Islam." (TV, 2004)
\end{abstract}

From this framework, humanity in general and Muslims in particular are allowed to explore the cyber world, take as much as possible the opportunities from this technology and jettison its evils. Islam an all encompassing religion without which man would have destroyed himself due to the free-will Allah (the Creator) endowed him with must therefore regulates the use of the technological growth. The presence of Islam in the cyber world according to Anderson (as cited in El-Nawawy \& Khamis, 2009) started from the phase of technological adepts, to correcting misrepresentations in Islam and to the Islam cyber evolution. This led to the creation of websites that developed educative, informative and interactive portals. The presence of Islam into cyber world has also created an opportunity for dialogue and created a new way of Da'wah.

As it has been confirmed, internet technology has a lot of paybacks as well as dark side. Many times man is 
beclouded only with its benefits and thereby forget about the consequences of this dark side. Hence the following sections will be highlighting some of the positive and negative impacts of the internet technology.

\title{
2. Positive Impacts of the Internet
}

\subsection{Education}

Internet technology provide access to free education such as easy accessing/downloading of academic materials from MIT (Zaidi, 2012). Youtube online videos also serve another platform for getting information on both academic and religious issue. It has assisted in dissemination of Islamic Knowledge, Adebayo wrote: "It is interesting to note that prominent books on figh like al-fatawa alfiqhiyyah alkubra,al-fatawa al-hindiyah, al-Turuq al-hukmiya, al-ahkam alSultaniyah, Fi zilal al- Qur'an of Sayyid Qutb and many others are readily available online for easy accessibility..." (Adebayo, 2010). Another practical example is the usage of internet in learning Arabic language (Muhammad \& Wan, 2007). Education which includes teaching, learning and imparting knowledge is a fundamental message of Islam. The Prophet (SAW) said: The seeking of knowledge is obligatory upon every Muslim (Mishkat); "The word of wisdom is the lost property of the believer, so wherever he finds it he has a better right to it" (Tirmidhi) and "He who goes forth in search of knowledge is in the way of Allah till he returns" (Tirmidhi). Adebayo (2010) supported this when he argued:

\begin{abstract}
"the Prophet regarded knowledge as a stray camel of the Muslims which must be taken wherever it is found. He also urged them to extend the scope of their knowledge by seeking knowledge even if it would take them to China. China was a far place to Arabian land that it could not be reached easily by then. A quick means of reaching China and even beyond now is through the use of the modern information and communication technologies and from which knowledge could be sought. Thus the challenges of seeking knowledge from far distance are taken care of by the modern ICT" (Adebayo, 2010)
\end{abstract}

Simulation of some of Islamic acts to facilitate learning and correct practise of those act (for example Hajj, Salat) is also a special example in this realm. Therefore, the cyber world has helped to create enabling environment where leaning becomes easier. Allah says: "... what Allah want for you in religion is ease and not difficulty..." (Al-Qur'an, alBaqarah: 184)

\subsection{Facilitate Easy Access to and Sharing of information}

Information is power. The technology has served as sources of information generally and to the Muslims in specific with the creation of the Islamic websites. With these websites, Islamic knowledge are disseminated and da'wah methodology is enhanced. Yusof al-Qardhawi stated that Internet is a very important tool in spreading Islamic teachings and it can be a platform to unite Muslim community.

\subsection{Relationships}

According to Michael Boyd, "Muslims around the world are making a connection with their faith through the Net. There are websites through which they learn about their religion, as well as how to spread it". Zaidi (2012) asserts that internet facilitates "keeping in touch with relatives across the globe". With this, ties of kinship can be strengthened which in turn results into love amongst families, strengthened bond and development of noble characters. Allah instructed: " $O$ Mankind! Fear your Lord, who created you from one soul and created from it its mate and dispersed from both of them many men and women. And fear Allaah, through whom you ask one another, and the wombs. Indeed Allaah is ever, over you, an Observer."(Al-Qur'an, an-Nisai:1) This verse is a confirmation that maintaining ties with relations is binding. The prophet (SAW) said: "He who desires ample provisions and for his life be prolonged should maintain good ties with his blood relations." (Al-Bukhaari \& Muslim).

It "expands human relationships beyond the normal form" according to wheeler (as cited in El-Nawawy \& Khamis, 2009). With this global community is created where people of like minds are attracted. Allah the most High says: "The Believers, men and women, are rotectors of one another" (Al-Qur'an, at-Taubah:71), and "Indeed the Believers are but brothers" (Al-Qur'an, al-Hujrat:10)

Having feelings and concern about the affairs other Muslims is a major aspect of Islam hence the technology creates avenue to genuine information about happenings in other muslim countries. The Prophet (may Allah bless him) 
said: "Any one of you who wakes up in the morning and does not care for the affairs of the Ummah (The Muslims), is not one of us". (Muslim)

\subsection{Real-time communication eg-video conferencing, tele-conferencing (Rosydi \& Muhammad, n.d.) .}

Real-time communications (RTC) was defined by Margaret (2008) as "any mode of telecommunications in which all users can exchange information instantly or with negligible latency". It involves technologies such as telemedicine, telehealth, telecommuting, e-health, telemarketing and host of others. Alexander \& Simon (2011) described some of the advantages of real-time communication (using telemedicine as a case study) as: "improved access to specialists; increased patient satisfaction with care; improved clinical outcomes; reduction in emergency room utilization and cost savings"

In the press release of Business Wire (2011), the Internet Innovation Alliance (IIA) identified some benefits of telemedicine, eHealth and health IT based on analysis from sources including the Department of Health \& Human Services and the U.S. Chamber of Commerce. The benefits according to IIA includes that telemedicine:

"Enables more informed decision making and enhanced quality of care; Saves lives through remote consultations, whether urgent or diagnostic; Creates more efficient, convenient and potentially more cost effective delivery of care; Facilitates earlier - and more accurate - diagnoses; Provides greater, and faster, access to a patient's medical history, reducing the risk of negative drug interactions or poor response to a course of treatment; Improves administrative efficiency and coordination; Allows rural residents to receive expert diagnosis and treatment from distant medical centers; Increases timeliness of treatment and decreases transfer rates while reducing medical costs through video technology; Supports real-time treatment by first responders through the use of wireless devices and Enhances senior wellness and preventative care through telemedicine and remote in-home monitoring." (Wire Business, 2011)

\section{Allah says:}

"On that account We ordained for the Children of Isra'il that if any one slew a person - unless it be for murder or for spreading mischief in the land - it would be as if he slew the whole humanity: and if any one saved a life, it would be as if he saved the whole humanity. Then although there came to them Our messengers with clear (guidance), yet, even after that, many of them continued to commit excesses in the land." (Al-Qur'an, Al-Maidah:32)

With the above gadget, attention is paid in earnest to the life of the sick and treatment is administered to time.

\subsection{E-Commerce}

E-commerce is another major benefit of the technology. Kunii (2004) states:

Cyber worlds are closely related to the real world we live, intentionally or unintentionally. In certain areas, they have grown in their scales far beyond those of the real world. For example, in financial trading, a daily trading in the cyberworlds of e-trading in its amount is far beyond that of GDP (Kunii, 2004).

Zwass (1996) defines Electronic commerce (E-commerce) as "the sharing of business information, maintaining business relationships, and conducting business transactions by means of telecommunications networks" while Elsie Chan \& Paula M. C. Swatman (n.d.) defines electronic commerce as principally imply "the undertaking of normal commercial, government and personal activities by means of computers and Telecommunications networks that includes a wide variety of activities involving the exchange of information, data or value-based exchanges between two or more parties". The same concept was defined by Minoli and Minoli (as cited in Jerry Gao, 1999) to mean "the symbiotic integration of communications, data management, and security capabilities to allow business applications within different organizations to automatically exchange information related to the sale of goods and services." Treese and Stewart (as cited Jerry Gao, 1999) described the concept to include "...the use of computing and communication technologies in financial business, online airline reservation, order processing, inventory management..."

All parties in the business transaction had been surveyed to benefit from the e-commerce; consumer, organization and the society Vuylsteke \& Faser (2011) writes:

"Electronic commerce is believed to benefit businesses by reducing transaction costs, facilitating the development of geographically dispersed markets and improving coordination between cooperating parties (Robey, et al., 1990; 
UNCTAD, 2001; UNECA, 1999). These benefits have been assessed in a number of studies of large and small businesses. (Fey, et al., 2006; Fitzgerald, et al., 2005; Poon and Swatman, 1999)."

The work of Zainul, Osman and Mazlan (2004) described the Islamic perspective to e-commerce. Hussin (as cited in Zainul et al. 2004) argues:

"Islam accepted the conduct of E-Commerce as a new way or technology to facilitate economic transactions. This is based on the Syariah (Islamic Law) legal values, namely the obligatory (Wajib), recommended (Mandub), permissible (Mubah), reprehensible (Makruh), and forbidden (Haram)."(Zainul, Osman, \& Mazlan, 2004)

Citing the interview conducted with Ustaz Mustafa Omar of International Islamic University, Malaysia (IIUM) Zinul et al (2004) reported that Ustaz Omar argues:

\begin{abstract}
"Islam is not against E-Commerce. Islam basically encourages E-Commerce as a new way of conducting business. Traditionally, business was conducted verbally face to face but today the two contracting parties are connected together via computer. However, there are conditions that need to be observed for the validity of E-Commerce in Islam. According to most scholars, there are four pillars of Islamic contract, namely ijab and qabul, two contracting parties, the subject matter and sigha (the mode of expressions). Traditionally, when two contracting parties involved in a contract, the place is called 'majlis' (meeting) where both parties communicate face to face. Today, with the emergence of ECommerce, we have to redefine 'majlis' as the communication which takes place via computers". (Zainul et al 2004)
\end{abstract} affirm:

When again asked about the type of contract where e-commerce fall, ustaz Umor (as cited in Zainul et al, 2004)

\begin{abstract}
"Ecommerce may fall under any of the three types of Islamic contract mentioned above, depending on the mode of communication and the type of business being conducted. When a company which is conducting sales online took the money first from the customer and delivered the product in the future, it is an Ordered Sale. If the company made an agreement with the customer to produce the product ordered and take money from the customer only after the product is made, it is manufacturing Sale. And if the company agreed to sell the product to the customer in deferred price or in instalment, then it is a Deferred Sale".
\end{abstract}

Among other benefits is the use of Electronic Mail (e-mail) which creates avenue for people to communicate via sending, receiving and reading messages electronically. This saves time when compared to other forms of communication. Listserv, Newsgroup and Web-based Forum. These applications basically allow the internet users exchange and share information digitally. Hence, it enables Muslim scholars situated in different parts of the ummah to virtually gather in order to discuss, debate and solve problems as well as challenges facing the ummah. The prophet said: "Whoever does not feel concern about the affairs of the Muslims is not part of us". With this Islam encourages listening to news in order to know the happenings around the world, with mind to learn and contribute to the development of mankind.

\title{
3. Negative Impacts of the Internet
}

Several people have been victims of the cyber-crimes intentionally or unintentionally, teenagers and children are no exemption. This is due to the fact that it's a technology that is free for all. The following discuss some of the crimes in the cyber world that have been condemned morally and religiously.

\subsection{Internet Gambling}

This is one of the crimes that exist in the cyber world. According to Geis \& Brown (2006) some people see internet gambling as a relation and time-out activity, while others feel it can be a source of trap. Smith, G., Hodgins, D., \& Williams, R.J. (eds.) 2007 stated: "virtually mediated casino games, slot machines, bingos, lotteries, sports wagering, horse race betting, and skill games are all now readily accessible, with new forms of gambling and new sites being added each year". This shows the various forms the internet gambling could take. But Allah has warned in Al-Qur'an:

"O you who have believed, indeed, intoxicants, gambling, [sacrificing on] stone alters [to other than Allah], and divining arrows are but defilement from the work of Satan, so avoid it that you may be successful. Satan only wants to cause 
between you animosity and hatred through intoxicants and gambling and to avert you from the remembrance of Allah and from prayer. So will you not desist?" (Al-Qur'an, al-Maidah: 90)

In clear terms, Islam prohibits any form of gambling because of its bad consequence which are hatred and enmity.

\title{
3.2 Digital Piracy
}

Another form of criminal behaviour through the growth of the internet technology is the digital piracy. Gopal, Sanders, Bahattacharjee, Agrawal, \& Wagner (as cited in Higgins, 2004, 141) defines digital piracy as "illegal copying of digital goods, software, digital documents, and digital audio (including music and voice) for any reason other than to back up without the explicit permission from and compensation to the copyright holder". Faraz Rabbani (2003) in an online fatwa argues that some of the Islamic scholars of the recent time have professed that copyright laws are completely binding. He stated that intellectual property in the society of today is the most valued asset and that copyright law in no way impede the spread of knowledge. I his comments he said that the scholars like Shaykh al-Buti, Shaykh Zuhayli, Shaykh Taqi Usmani, Shaykh Sunbuhli, and others, including the major fiqh councils hold copyright to be binding and breaking the copyright law is sinful (Rabbani, 2003).

\subsection{Online Victimization}

Even though the Internet makes available wealth of information and opportunities to youth, as with any other aspect of their lives the total reliance on the computer technology increases cybercrime rate and affects all and sundry in all sphere of life. The US Department of Justice described how teenagers and children are captured by the perpetrators of the internet crime in the online OVC bulletin:

\begin{abstract}
"Predators contact teenagers and children over the Internet and victimize them by enticing them through online contact for the purpose of engaging them in sexual acts, using the Internet for the production, manufacture, and distribution of child pornography, using the Internet to expose youth to child pornography and encourage them to exchange pornography, enticing and exploiting children for the purpose of sexual tourism (travel with the intent to engage in sexual behaviour) for commercial gain and/or personal gratification" (Gillis, 2011).
\end{abstract}

From the afore-mentioned cybercrimes and forms of victimizations from the criminals both human society and religion body have categorized online victimization has a condemnable act whichever form it takes. Islam warns through Al-Qur'an":

"O you who believe! Stand out firmly for justice, as witnesses to Allah, even though it be against yourselves, or your parents, or your kin..." (Al-Qur'an, an-Nisaa: 135),

and

"O you who believe! Be upright for Allah, bearers of witness with justice, and let not hatred of a people incite you not to act equitably; act equitably, that is nearer to piety, and he careful of (your duty to) Allah; surely Allah is Aware of what you do" (Al-Qyr'an, al-Mai'dah:8)

Sometimes the online victimization takes the form of distribution of harmful software in form of viruses (Holt, 2003) which in turn destroys the computer data files and can lead to identity theft. The holy Prophet Muhammad (SAW) said: "do not transgress and do not allow yourself to be transgressed upon"

\subsection{Cyber Stalking}

With its overwhelming capabilities, the internet technology also opened holes-in-the-wall in the cyber world for criminals to involve in what is called cyber stalking. Pittaro (2005) describes cyber stalkers as those who "uses the Internet as a weapon or tool, of sorts, to prey upon, harass, threaten, and generate fear and trepidation in his or her victims through sophisticated stalking tactics, which, for the most part, are largely misunderstood and, in some cases, legal". Literatures have not been able to give a universally accepted definition to cyber stalking. Petrocelli and Reno (as cited in Pittaro, 2005,278 ) states "the term commonly denotes to the use of the Internet, e-mail, or other electronic communication 
gadget to create a criminal level of intimidation, harassment, and fear in one or more victims". Islam warns against the act of mischief as stalking can be seen as a mischievous act. Allah says:

But seek, through that which Allah has given you, the home of the Hereafter; and [yet], do not forget your share of the world. And do good as Allah has done good to you. And desire not mischief in the land. Indeed, Allah does not like mischievious." (Al-Qur'an, al-Qasas: 77)

\subsection{Cyber Bulling}

Cyber bullying is another form of crime in the virtual world. It is a deceptive character because of its unidentified style. The cyber bullying is similar to the traditional bullying which can be open (as in beating or sexual touching) or hidden (as in gossiping or harassment) (Hoff, n.d.). The personality that the human world desires is the one the creator of all, Allah the Almighty, describes as below:

"And the servants of the Most Merciful are those who walk upon the earth easily, and when the ignorant address them [harshly], they say [words of] peace" (Al-Qur'an, al-Furqaan: 63).

"And do not turn your cheek [in contempt] toward people and do not walk through the earth exultantly. Indeed, Allah does not like everyone self-deluded and boastful. And be moderate in your pace and lower your voice; indeed, the most disagreeable of sounds is the voice of donkeys." (Al-Qur'an, Luqman: 18-19)

The best example for mankind also gave the type of model human being generally and the Muslims in particular should be in the following sayings:

"There is nothing heavier than good character put in the scale of a believer on the Day of Resurrection." (Abu Daud)

"I have been sent only for the purpose of perfecting good morals" (Al-Muwatta).

"A true Muslim is he from whom Muslims are safe from his tongue and his hand, and a true muhaajir is one who abandons what Allah has forbidden." (Bukhari)

"Narrated Abdullah ibn Amr ibn al-'As: The Prophet said: Those who do not show mercy to our young ones and do not realize the right of our elders are not from us". (Abu Dawud)

"The Prophet said: He does not belong to us who does not show mercy to our young ones and respect to our old ones, who does not recommend what is reputable and prohibit what is disreputable". (At-Tirmidhi).

"Those who are merciful will be shown mercy by the Merciful. Be merciful to those on the earth and the One above the heavens will have mercy upon you. The womb is derived from the Merciful, so whoever keeps relations with his family then Allah will keep relations with him, and whoever abandons his family then Allah will abandon him." (At-Tirmidhi)

All these pointed out the fact that over or covert bullying is not acceptable in Islam.

\section{Concluding Remarks}

Islam allows the use of the internet technology as there are immense benefits including dissemination of Islamic messages, easy access to information, creation of enabling environment to implement Islamic instructions and reservation of knowledge. However this enormous benefit runs parallel with the negative sides of this tool. It has created various cyber- crimes and because of its insecurity nature parents, guardian and governments need to be proactive so as to cub the ever growing crimes in the cyber world and guide the teenagers.

\section{References}

Adebayo, R. I. (2010). The Challenges and Opportunities of Islamic Studies in the World of Modern Cyber-Technologies: The Nigeria Example. In Regional Conference on Knowledge Integration in ICT (pp. 272-280).

Alexander Vuylsteke, \& Simon Faser. (2011). The Impact of Industry Structure on E-commerce Initiatives in the Developing World: Two Cases Studies from Triniad and Tobago. First Monday. Retrieved December 12, 2013, from http://firstmonday.org/ojs/index.php 
/fm/article/view/3377/3046

Al-Naquib-Al-Attas, S. M. (1978). Islam and Secularism (p. 74). Kuala Lumpur, Malaysia: Art Printing Works Sdn Bhd.

El-Nawawy, M., \& Khamis, S. (2009). Islam Dot Com (p. 269). USA: Palgrave Macmillan.

Elsie Chan, \& Paula M. C. Swatman. (1999). Electronic Commerce : A Component Model E-Commerce Frameworks / Models. In 3rd Annual CollECTeR Conference on Electronic Commerce (pp. 1999-1). Wellington, New Zealand.

Geis, G., \& Brown, G. C. (2006). Internet Gambling. In K. Jainshankar (Ed.), Cyber Criminology: Exploring Internet Crimes and Criminal Behaviour (pp. 13-28).

Gillis, J. W. (2011). Internet Crimes Against Children. Retrieved from http://www.ojp.usdoj.gov/ovc/publications/bulletins/internet 2 2001/

Higgins, G. E. (2011). Value and Choice. In K. Jainshankar (Ed.), Cyber Criminology: Exploring Internet Crimes and Criminal Behaviour (pp. 141-154). CRC Press, Taylor \& Francis Group.

Hoff, D. L. (n.d.). Cyber Bullying. In K. Jainshankar (Ed.), Cyber Criminology: Exploring Internet Crimes and Criminal Behaviour (pp. 359-392). CRC Press, Taylor \& Francis Group.

Holt, T. J. (2003). Malware Victimization. In K. Jainshankar (Ed.), Cyber Criminology: Exploring Internet Crimes and Criminal Behaviour (pp. 317 - 343). CRC Press, Taylor \& Francis Group.

Jerry Gao. (1999). Introduction To E- Commerce. Retrieved December 10, 2013, from https://www.uop.edu.jo/download/research Imembers/introduction.pdf

Klastrup, L., \& Tosca, S. (n.d.). Transmedial Worlds - Rethinking Cyberworld Design. In 2004 International Conference on Cyberworlds (pp. 409-416). leee. doi:10.1109/CW.2004.67

Kunii, T. L. (2003). Algebraic Topological Modeling for Cyberworld Design, (December), 3-5.

Kunii, T. L. (2004). The Potentials of Cyberworlds -An Axiomatic Approach- Kanazawa Institute of Technology.

Margaret Rouse. (2008). real-time communications (RTC). SearchUnifiedCommunications. Retrieved December 11, 2013, from http://searchunifiedcommunications.techtarget.com/definition/real-time-communications

Mohamed, D. bt. (2011). Islam in Cyber Environment and the Legal Issues in Malaysia. In New Media and Islamic Issues: Challenges and Opportunities (pp. 1-27). Kuala Lumpur, Malaysia.

Muhammad, M. I., \& Wan, M. B. M. (2007). The Usage of the Internet in Learning Arabic Language. In A. R. Azman, M. T. E. Hisham, \& A. Hishomudin (Eds.), The World Today: CURRENT GLOBAL ISSUES In conjunction with te 50th Independency Day (first., pp. 17 - 32). Malaysia: Center for General Studies, Islamic Science University of Malaysia.

Pittaro, M. L. (2005). Cyber Stalking, 277-297.

Rabbani, F. (2003). Can I Pirate Sh. Hamza's New CDs. Qibla - for The Islamic Sciences | Learn, Change, Inspire. Retrieved October 20, 2013, from http://spa.qibla.com/issue_view.asp?HD=1\&ID=632\&CATE=115

Rosydi, M., \& Muhammad, B. I. N. (n.d.). Using information and Communication Technology (ICT ) to disseminate the Understanding of Islamic Jurisprudence ( FIQH ) and Juridical Opinion (FATWA ).

TV, A.-J. (2004). Qatar: Islamic Cleric Al-Qaradawi says internet part of "contemporary jihad." Doha: BBC Monitoring Media. Retrieved from http://www.biyokulule.com/view_content.php?articleid=5304

Wire Business. (2011). 10 Benefits of Telemedicine, eHealth and Health IT. Retrieved December 09, 2013, from http://www.businesswire.com/news/home/20110728006848/en/10-Benefits-Telemedicine-eHealth-Health

Zaidi, M. (2012). Parenting and the Cyber World. ISLAMIC INSIGHTS. Retrieved September 20, 2013, from http://www.islamicinsights.com/features/technology/parenting-and-the-cyber-world.html

Zainul, N., Osman, F., \& Mazlan, S. H. (2004). E-Commerce from an Islamic perspective. Electronic Commerce Research and Applications, 3(3), 280-293. doi:10.1016/j.elerap.2004.01.002

Zwass, V. (1996). Electronic Commerce : Structures and Issues. International Journal of Electronic Commerce, 1(1), 3 - 23. 